\title{
Predicting Current and Future Geographical Distribution of Araucaria in Brazil for Fundamental Niche Modeling
}

\author{
Marcos Silveira Wrege ${ }^{1, *}$, Valderês Aparecida de Sousa ${ }^{1}$, Elenice Fritzsonss ${ }^{1}$, Márcia Toffani Simão Soares ${ }^{2}$, \\ Ananda Virgínia de Aguiar ${ }^{1}$ \\ ${ }^{1}$ Research at Embrapa Florestas, Estrada da Ribeira, km 111, Colombo (PR), Brazil \\ ${ }^{2}$ Research at Embrapa Pantanal, Brazil
}

Copyright $(2016$ by authors, all rights reserved. Authors agree that this article remains permanently open access under the terms of the Creative Commons Attribution License 4.0 International License

\begin{abstract}
Geographic distribution forecast of Araucaria angustifolia (Bertol.) O. Kuntze. was studied. This is a native species that occurs more frequently in the southern region of Brazil and, to a lesser extent, in the southeasthern region. The study was based on points of occurrence that were collected over several years by Embrapa Forests and complemented by points obtained from herbaria, banks and several educational institutions, including the biological collections database Reference Center Environmental Information (CRIA), which gathers information from various herbaria in Brazil. We used mathematical models occurrence prediction, including: Bioclim, and Niche Mosaic. The models were selected for best representing the regions of occurrence. In addition to the points of occurrence, to compose the spatial modeling environmental data, climate, soil, and topography were needed. In the study we used only climate data such as the average minimum air temperature, average maximum air temperature, accumulated rainfall, and average relative humidity. We didn't use soil data because there was not a detailed survey available throughout the area of occurrence of the species. We conclude that the naturally occurring region of Araucaria was well represented using only the climate data and two models that well represented the occurrence of regions. With climate change, there is a strong tendency to reduce the potential area of Araucaria in Brazil, especially in regions at lower latitudes and altitudes.
\end{abstract}

Keywords Araucaria, Ecological Modelling Niche, Potential Distribution Model, Realized Niche, Genetic Conservation, Climate Change

\section{Introduction}

Araucaria is the most representative native tree species of the coldest regions in Brazil. It is present in the south and southeast regions of the country. Its occurrence can be predicted by ecological niche models, which relates the incidence of local species to climate and soil variables, through mathematical algorithms. In the following paragraphs, the importance of Araucaria as well as a description of potential distribution modeling is explained.

\subsection{Considerations about Araucaria and Araucaria Forest}

Araucaria angustifolia (Bertol.) O. Kuntze. is a native species of high socio economic importance in Brazil. It is found more often in the southern region at altitudes above 500 meters and less frequently in the southeastern region which is present at higher altitudes than the south. This is a very significant area where the climate is temperate, according to Köppen classification (Wrege et al., 2011) [35] and $A$. angustifolia is widely dispersed in this region.

The geographical distribution of $A$. angustifolia and the region of its occurrence is called Araucaria Forest or Ombrophilous Mixed Forest (FOM) and it is defined by climatic conditions: lower temperature with frost.

Currently, the hot and humid climate favors the expansion of the dense rainforest and semideciduous forest on the Ombrophilous Mixed Forest (Klein, 1960, 1984 [18, 19]. It is unlike what occurred in past geological eras, when the climate was cooler. During this time, Araucaria was found more dispersed over a larger area; in lower latitudes and altitudes than the current.

At present, in the south and southeast regions of the country, the mid-latitudes, along with the geographical (relief) conditions, provide the creating of microclimates that support the existence of $A$. angustifolia genetic diversity. Those phenotypic differences are responsible for the existence of many varieties or geographical races (Reitz and Klein, 1966 [19, 28]). In Despite of the socio-economic importance of this species, there are no significant scientific studies of taxonomy, genetics, or breeding. Thus, some provenance and progeny tests are being made.

Specific studies made since 2000 using molecular or biochemical markers of $A$. angustifolia have not considered 
its whole area of occurrence. These studies showed differences between and within populations (Shimizu et al 2000 [29];. Sousa, 2001 [8]; Auler, 2002 [1]; Mantovani et al 2006 [22];. Puchalski et al 2006 [26]; Stefenon, 2007 [30]; Bittencourt and Sebbenn, 2007 [3]) identified two distinct groups. One group is located in the northern region where the species occurs in the states of São Paulo and Minas Gerais, between the latitudes of $19^{\circ} 15^{\prime} \mathrm{S}$ and $23^{\circ} 27^{\prime} \mathrm{S}$. It rarely appears in the states of Rio de Janeiro and Espirito Santo. Another group is located in the south, between the latitudes of $23^{\circ} 27^{\prime}$ s and $31^{\circ} 30^{\prime}$ s at Tropic of Capricorn. Generally, altitudes above 500 meters in the forests are located in mountainous regions between southern Paraná and northern Rio Grande Sul between the longitudes of $41^{\circ} 30^{\prime} \mathrm{W}$ and $54^{\circ} 30^{\prime} \mathrm{W}$ (Valgas, 2008 [32]; Valgas et al 2009 [33]; Sousa et al, 2009 [9];. Fähser, 1981 [13]; Hueck, 1972 [14]; Carvalho, 1994 [4]). Although it predominantly occurs in Brazil, it still occurs in small areas of Argentina in the Province of Misiones and in Paraguay.

Expansion of agriculture and urbanization as well as indiscriminate exploitation of the species due to its commercial and social value has represented a major threat to Araucaria, putting them at risk of extinction (Dean, 1995 [12], IBAMA, 2009 [16]). Depending on the location, araucaria can have a yield of up to $30 \mathrm{~m}^{3} \mathrm{ha}^{-1} \mathrm{yr}^{-1}$, which corresponds to an increase in height from 1 to 1.5 meters in a year. Despite being productive, the species is not preserved. Currently the remnants of Araucaria Forest do not represent more than $7 \%$ of the original area (MMA 2002). In the state of Santa Catarina, only $2 \%$ of the area or $4,000 \mathrm{~km}^{2}$ are presented in scattered fragments (Medeiros, 2000) [23]. In Paraná it is also present in scattered fragments with less than 5,000 hectares at $0.8 \%$ of the forest that still remain at an advanced stage (Fupef, 2001).

There are some obstacles to the advancement in commercial plantations of the species. One of the factors that hinder it is the strict legislation which aims to protect it from extinction, preventing the cutting of native material (CONAMA Resolution n. 278 of May, $24^{\text {th }}$ 2001). The law is interpreted incorrectly, with the permission for cutting an area with commercial planting, if it is proven to be commercial and there is no restriction for commercial exploitation. This misunderstanding has hampered planting and the effect has been the opposite of what has been expected. Farmers have eliminated regenerations occurring outside protected areas, believing that they can constitute hindrance to the development of future agricultural activities, when the trees grow and no more can be extracted.

There are studies about the possibility of conservation by means of rational logging management (conservation on farm). On farm the conservation made by local community is essential for the preservation of the species.

Faced with these problems, it is important to identify the native remaining of Araucaria by focusing its preservation. The preservation is a difficult and expensive task that requires a lot of field work. This work can be easier and less costly with the existence of species localization maps in the field. These Maps can be made with the ecological niche modeling.

\subsection{Ecological Niche Modeling}

First, it is necessary to define the difference between fundamental niche and realized niche. The first describes the abiotic conditions in which species are able to survive while the second describes which species persist in despite of the presence of others species. Both niches conducted refer to a particular moment in time and may change over time (Jimenez-Valverde et al., 2008) [17].

The ecological and potential niche modeling (MDP) enables the identification of the fundamental niche of the species by modeling species distribution. This is based on the relationship between environmental attributes where the species lives (its ecological niche) and the climate, soil, and relief. The detail level may vary in species and in population. Thus, information available can identify different populations and define areas where they occur. It can also contribute to the environmental characterization of their niches (Peterson, 2001 [25]; Raxworthy et al. 2003 [27]; Luoto et al., 2005 [21]).

Ecological niche modeling defines the species potential distribution. There is a difference between potential and actual distribution. The first refers to the place where the species could live and the second is the place where they really live (Jiménez-Valverde et al., 2008 [17]), considering the presence of other species and competition between them by remaining in the niche. The species are not isolated in their habitat. Presence of other species can change the survival conditions and define new relationships between them (Huntley et al., 2004 [15].

The ecological niche modelling is able to generate accurate predictions of the species occurrence using good quality data, with the maximum points that represent faithfully the region where the species occurs (Jiménez-Valverde et al., 2008) [17].

The model to be chosen is the best representation, that is, the model that has the least expected difference.

The ecological niche modeling may have several purposes, including analyzing the effect of global climate change on biodiversity; guiding selection of priority areas for conservation; making prediction of ideal areas for planting; guiding surveys to detect new species (rare or endangered); identifying new patterns of vegetation distribution; guiding surveys to detect the different populations of a species; detecting areas at risk for the invasion of exotic species and study possible routes for the spread of pests and diseases (Muñoz et al., 2009) [24].

The aim of this study was to investigate the possibility of mapping the current areas of occurrence of Araucaria in Brazil by using only climatic variables; and to define priority areas for environmental preservation; considering climate change, targeting the genetic material guard for future, taking into account the use of araucaria for reforestation and commercial plantations. 


\section{Materials and Methods}

This study was conducted in the regions of occurrence of Araucaria (Araucaria angustifolia). The potential geographical limits were based on the climatic characteristics of the regions where the species occurs naturally. It also studied the effects of climate change on areas where the species are present, based on climate models of Eta RCM (regional climate model) HadGEM2-ES. This model encompasses all of South America, Central America, and the Caribbean, according to the 5th Intergovernmental Panel Report on Climate Change (AR5/IPCC). Regional adaptations were made by the National Institute for Space Research in Brazil (INPE), according to Chou et al. (2014) [5].

First, the completeness and consistency dataset was analyzed (points of occurrence of $A$. angustifolia). The outliers were eliminated after a previous analysis, because these areas did not represent the natural occurances of the species. There is the possibility that these points eliminated are in plantations outside of the natural occurring zone because they are distant and isolated from the natural forests or forest fragments.

581 occurrence points of $A$. angustifolia in Brazil were gathered from different sources. Field data belonging to Embrapa Forests were collected over several years by Dr. Valderes Aparecida de Sousa, Embrapa researcher. The research literature data were obtained from theses from various brasilian institutions (Esalq, Unesp, UFPR, etc.) and from the database of biological collections of the Environmental Information Reference Center (CRIA) (http://www.cria. org.br/). CRIA combines historical information from various sources (herbaria present throughout Brazil), associated with a geographical distribution of species forecasting system, based on mathematical modeling.

The current and forecasting maps were developed using multiple linear regression. Climate variables were correlated employing the land surface model (altitude, in meters above sea level), the latitude, and longitude (decimal degrees).

The geographical distribution of occurance prediction was made by two mathematical models: Bioclim, and Niche Mosaic. The models were selected, which came closest to the natural geographic distribution of $A$. angustifolia.

Only climate variables were used. Soil date was not considered due to the extent of the occurrence in the region (very wide) and the difficulty in obtaining regional data. The climate data used were based on the average maximum and minimum air temperature, average accumulated rainfall, and average relative humidity in the summer (December, January, and February), fall (March, April, and May), winter (June, July and, August), and spring (September, October, and November).

The software used was Open Modeller (Muñoz et al., 2009) [24], ecological niche modeling software (http://openmodeller.sf.net), that used geographical data of species (latitude and longitude) map and environmental layers (climate, soils, relief, etc.); making a mathematical geographic species distribution forecasting system. In this study, we define sites prioritized to conserve natural populations and to establish new plantings of Araucaria.

\section{Results and Discussion}

In this study, two models were used to predict the naturally occurring regions of $A$. angustifolia in Brazil: Bioclim and Niche Mosaic. Both relate the occurrence of local species to climate variables, mainly the air temperature and rainfall.

The grey areas of the maps (Figures 1 and 2) represent the current areas of $A$. angustifolia, defined by Bioclim and Niche Mosaic models. The white zones represent potentially restricted areas of occurrance, because they do not join climatic conditions necessary for the full development of the species. The same is true for the representative maps of future scenarios (Figures 3 and 4). They represent potential regions for development of Araucaria in 2040, 2070, and 2100, in two different scenarios: Representative Concentration Pathway (RCP) 4.5, less pessimistic, and RCP 8.5, more pessimistic (Chou et al., 2014) [6].

Few layers of climate variables were used for modeling of Araucaria distribution and to define the limits for potential occurrance. This indicates that a limited number of climate variables were sufficient to model the occurrence of Araucaria zones as well defined by Huntley et al. 2004[15]: "The distribution of species from different taxonomic groups, representing different forms of life and trophic levels that can be modeled successfully using a limited number of bioclimatic variables".

Simulation of the potential areas for A. angustifolia in the current period was significant $(\mathrm{p}<0.001)$ and showed high levels of AUC (Area Under Curve) $(0.9 \pm 0.001)$, and $0 \%$ of omission error.

The generated map resulted in a potential area for Araucaria corresponding to $29,298,361$ hectares (Bioclim) and 37,851,745 hectares (Niche Mosaic). The most significant areas are in the Southern and Southeasthern mountainous regions of Brazil.

Araucaria may reach just over 2400 meters at medium altitude located around 1000 meters (Table 1). The lowest elevation is 9 meters, but generally is above $400-500$ meters. Winter average minimum temperature is $9.5^{\circ} \mathrm{C}$, reaching $-2.9^{\circ} \mathrm{C}$ (average of absolute minimum temperatures) and Summer average maximum temperature is $25.9^{\circ} \mathrm{C}$, reaching up to $40.7^{\circ} \mathrm{C}$ (mean absolute maximum temperatures).

Current composition of the Araucaria Forest has a close relationship with the past when several episodes of climatic fluctuations occurred over time in different geological eras that influenced the expansion and the retraction of the $A$. angustifolia occurrence zones.

Forests refuge in the deep valleys in cooler and dry periods and later in more humid and warm periods expanded to other regions of higher latitude and altitude, where cooler 
temperatures and higher humidity were kept (Ledru et al., 1996; Behling, 2005) [20, 2].

This phenomenon of shrinkage and expansion led to the discovery of the existence of several species of Araucaria that were distributed throughout South America and Australia (Wrege et al., 2009 [34]). In the future with climate change, the species are more expectedly found frequently in areas with the greatest latitude and altitude, where the climate is milder and the humidity higher (Chou et al., 2014) [5]. As it can be seen in Figures 3 and 4, there is a clear decline in areas favorable for the occurrence of the species, also due to the expansion of other types of forest formations surrounding the Ombrophilous Mixed Forest (FOM).

The current total combined area with potential for the grow of the species is just over 37 million hectares as defined by the Niche Mosaic model and just over 29 million hectares based on the Bioclim model, and the largest area is in the south and the smaller area is in the southeastern region of the country. Future occurrence of Araucaria maps projected a significant reduction of the potential area. The first model of future climate scenario, (RCP) 4.5, the less pessimistic model, projects a smaller reduction and the second, RCP 8.5, is more pessimistic and projects a significant reduction of the area, reaching near extinction of the areas for the development of the species in 2100 (Tables 2 and 3).

In a few decades major changes will occur, which may cause an increase in air temperature from $1.8^{\circ} \mathrm{C}$ to $6.3{ }^{\circ} \mathrm{C}$ and which has no historical precedent. In past geological ages, when there were climate change, the changes were slower, over hundreds of generations, allowing the evolutionary mechanisms to act.

The current scale of change began several years to a maximum of 100 years. Therefore, there was not enough time for the long-cycle species such as Araucaria to adapt. The possibility of extinction of these species can even work together to further the increase of emissions of greenhouse gases in the atmosphere (Wrege et al., 2009) [34].

A. angustifolia is a very vulnerable species although it has not yet been extinguished. Vulnerability can be manifested by changes in flowering and seed germination, which can reduce the regenerative capacity and lower growth rates. Furthermore, it will be aggravated by an increase of the attack of insects and pests. The intensification of forest fires and the increase of competition with invasive species will also be contributing factors. Maintenance of genetic diversity will be important for species adaptation to new environments. A greater genetic diversity represents the possibility for a better response to climate change.

The survival of $A$. angustifolia is linked to the capacity of dispersal of seeds and ability to reproduce, which will modify with climate change (Bittencourt and Sebbenn, 2007) [3], except in higher latitude and altitude regions. Although the dispersion capacity of its seeds is naturally restricted, their pollen can be carried over long distances. Currently, the natural regeneration of Araucaria has been shown to be poor in most areas studied. But, the diversity level in areas where regeneration has been considered sufficient to ensure survival of the species (Sousa et al., 2005; Stefenon et al. 2008) $[11,31])$, in spite of the long life cycle.

For long life cycle species, the process of adaptation should be much slower than expected (Hamrick, 2004). Also, the majority of negative effects that were caused by the decline and fragmentation of populations of $A$. angustifolia will be evidenced over many generations (Sousa, 2000) [10]. 


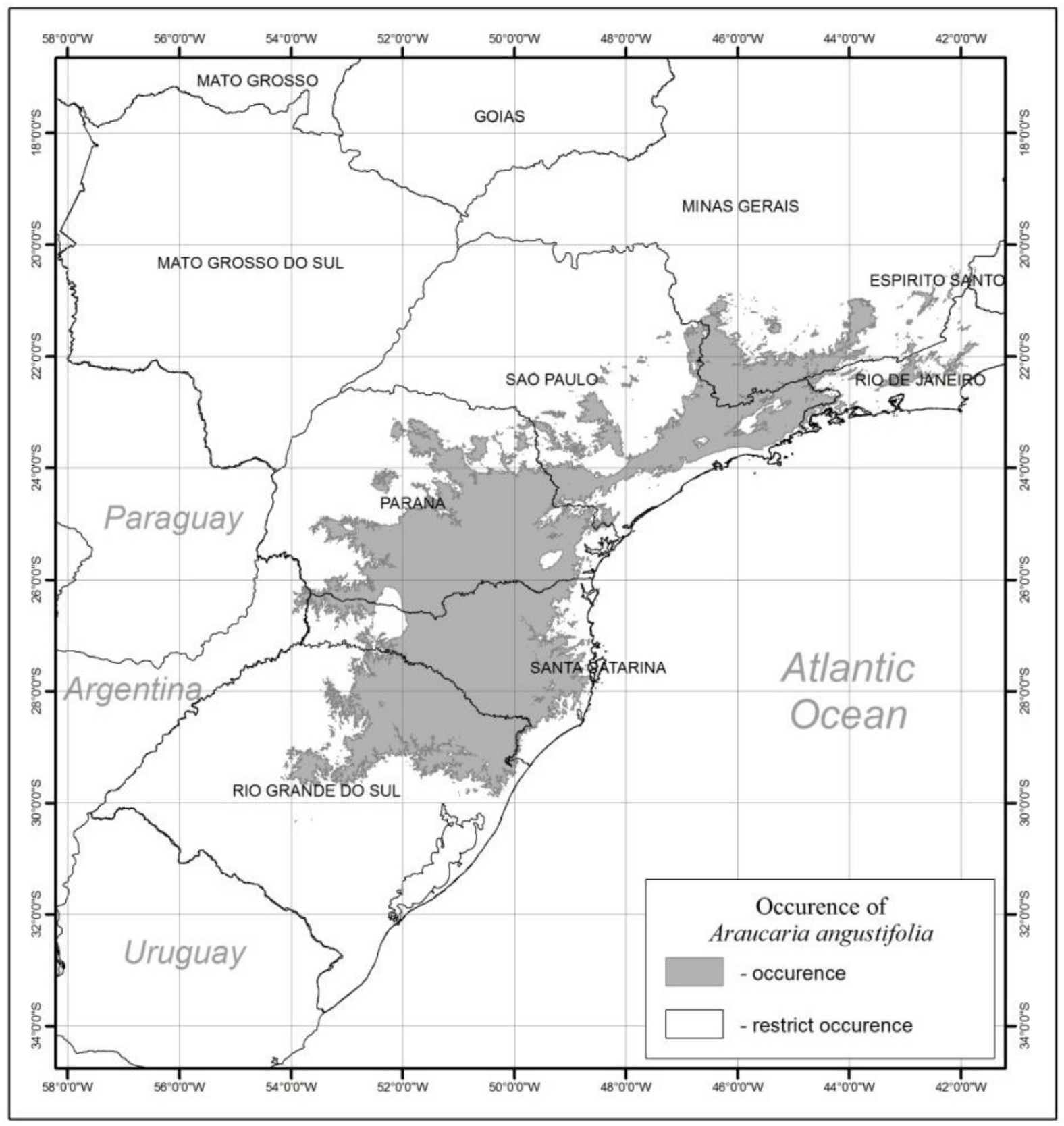

Figure 1. Fundamental niche occurrence of A. angustifolia based on Bioclim model. 


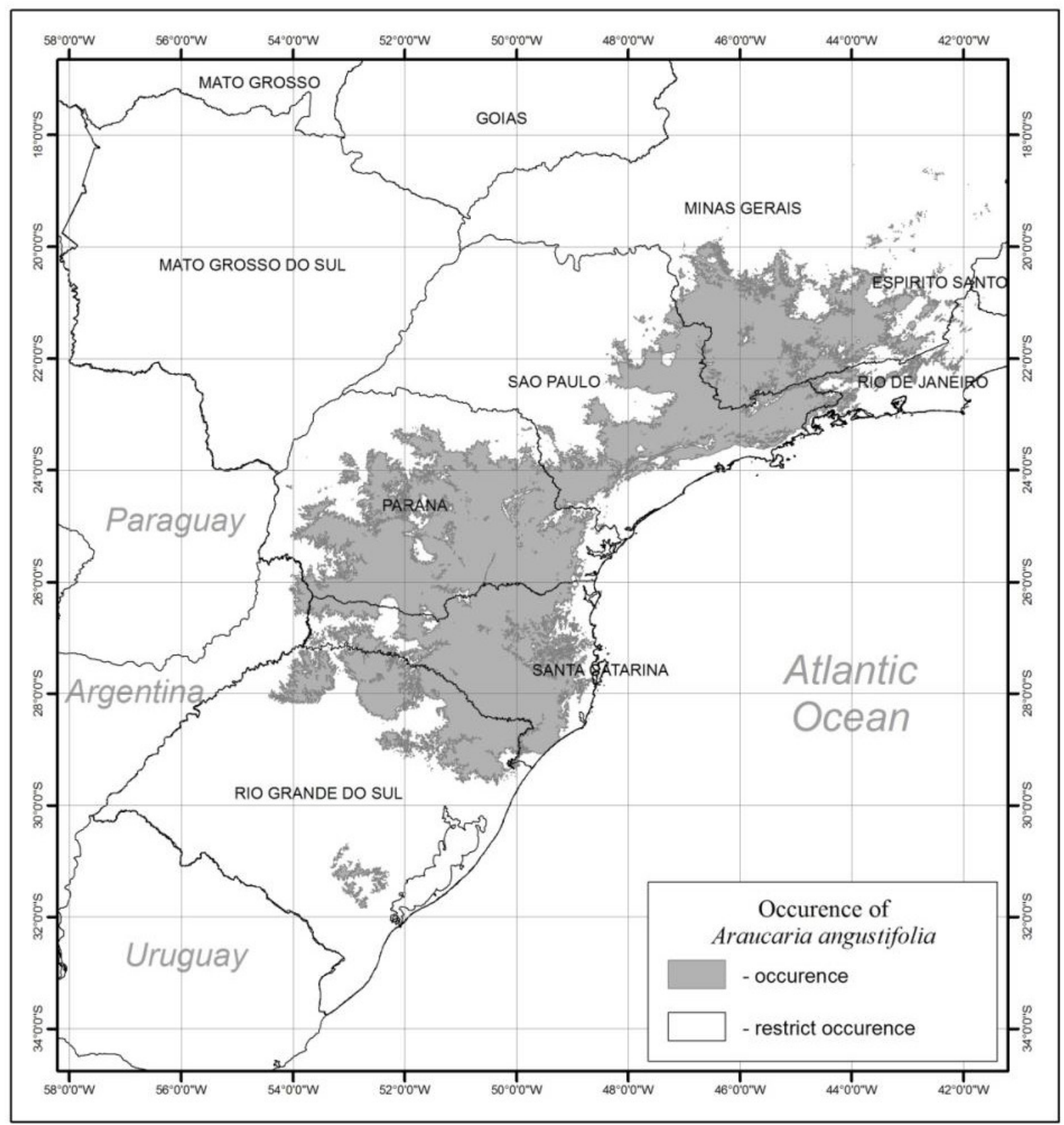

Figure 2. Fundamental niche occurrence of A. angustifolia based on Niche Mosaic model.

\section{Conclusions}

We conclude that the ecological niche models satisfactorily represent the potential occurrence of Araucaria areas. It is possible to predict areas that have great potential for the occurrence of the species and the potential distribution models can also help to understand the spatial distribution patterns of Araucaria.

By using mathematical modeling, we observe that there is a relationship between occurrence zones and climate.

Thus, it is possible to set the relationship model and climate variables to estimate the fundamental niche without requiring other environmental characteristics.
Although until recently, Araucaria has occurred in small fragmented areas, there are still large potential areas for its development. These occurrences may be greatly reduced in the coming decades, considering climate change. And the recovery of the areas with this species may occur with greater difficulty.

Araucaria areas of higher altitude in Parana, Santa Catarina and Rio Grande do Sul States should be prioritized for the purpose of preservation; aiming to protect the genetic material of the species.

Espírito Santo, Rio de Janeiro, Minas Gerais, São Paulo and Paraná States will experience a significant loss of potential areas for potential growth of A. angustifolia in the coming decades, in that order of importance. 
Table 1. Temperature data records in regions of occurrence of Araucaria, created by linear regression equations developed by Wrege et al. (2011) [35], relating to climate variables with the geographical latitude and longitude coordinates and altitude, to the points of occurrence of the species.

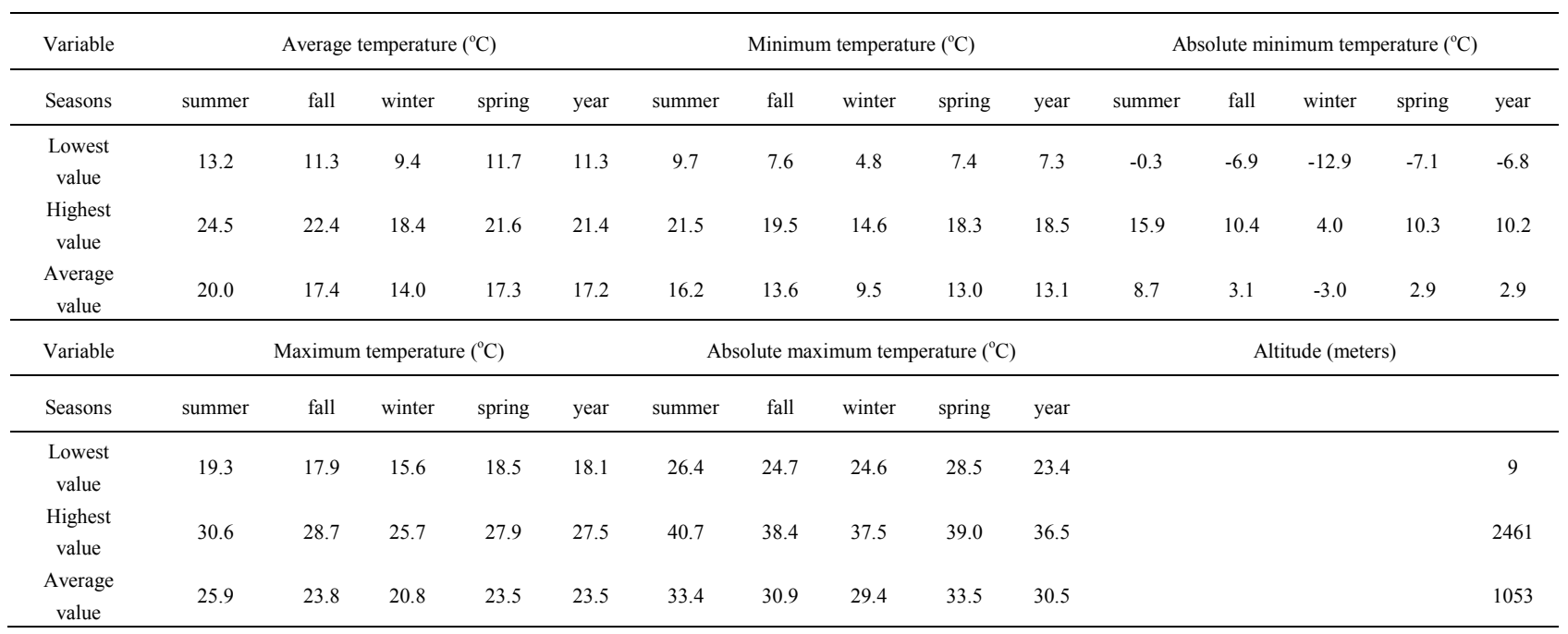

Table 2. Area (in hectares) with potential occurrence of A. angustifolia in the coming decades due to climate change, compared to the current area.

\begin{tabular}{cccccc}
\hline Algorithm & Current & Model /scenario & $2011-2040$ & $2041-2070$ & $2071-2100$ \\
\hline \multirow{2}{*}{ Niche Mosaic } & $37,851,745$ & RCP 4.5 & $20,125,537$ & $12,082,853$ & $9,353,085$ \\
& & RCP 8.5 & $12,708,690$ & $5,309,659$ & 92,809 \\
\multirow{2}{*}{ Bioclim } & $29,298,361$ & RCP 4.5 & $15,255,154$ & $7,903,796$ & $4,859,523$ \\
& & RCP 8.5 & $9,140,391$ & $2,823,471$ & 21,776 \\
\hline
\end{tabular}

Table 3. Area (in percentage) with potential occurrence of A. angustifolia in the coming decades due to climate change, compared to the current area.

\begin{tabular}{ccccc}
\hline Algorithm & Model/ scenario & $2011-2040$ & $2041-2070$ & $2071-2100$ \\
\hline \multirow{2}{*}{ Niche Mosaic } & RCP 4.5 & $53.17 \%$ & $31.92 \%$ & $24.71 \%$ \\
& RCP 8.5 & $33.57 \%$ & $14.02 \%$ & $0.24 \%$ \\
\cline { 2 - 4 } Bioclim & RCP 4.5 & $52.06 \%$ & $26.97 \%$ & $16.58 \%$ \\
& RCP 8.5 & $31.19 \%$ & $9.64 \%$ & $0.074 \%$ \\
\hline
\end{tabular}



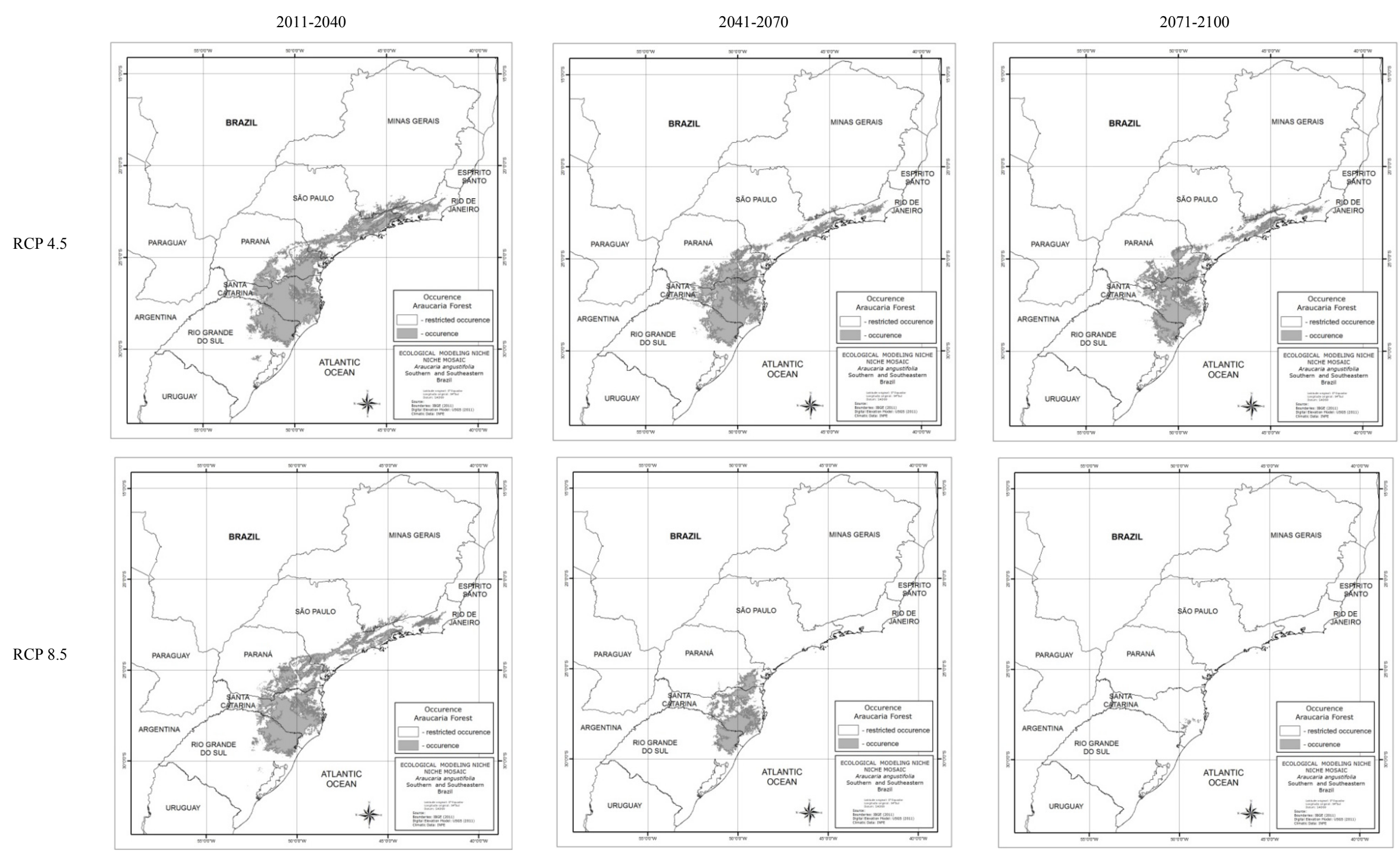

Figure 3. Changes in the fundamental niche occurrence of A. angustifolia based on Niche Mosaic model according to climate change. 

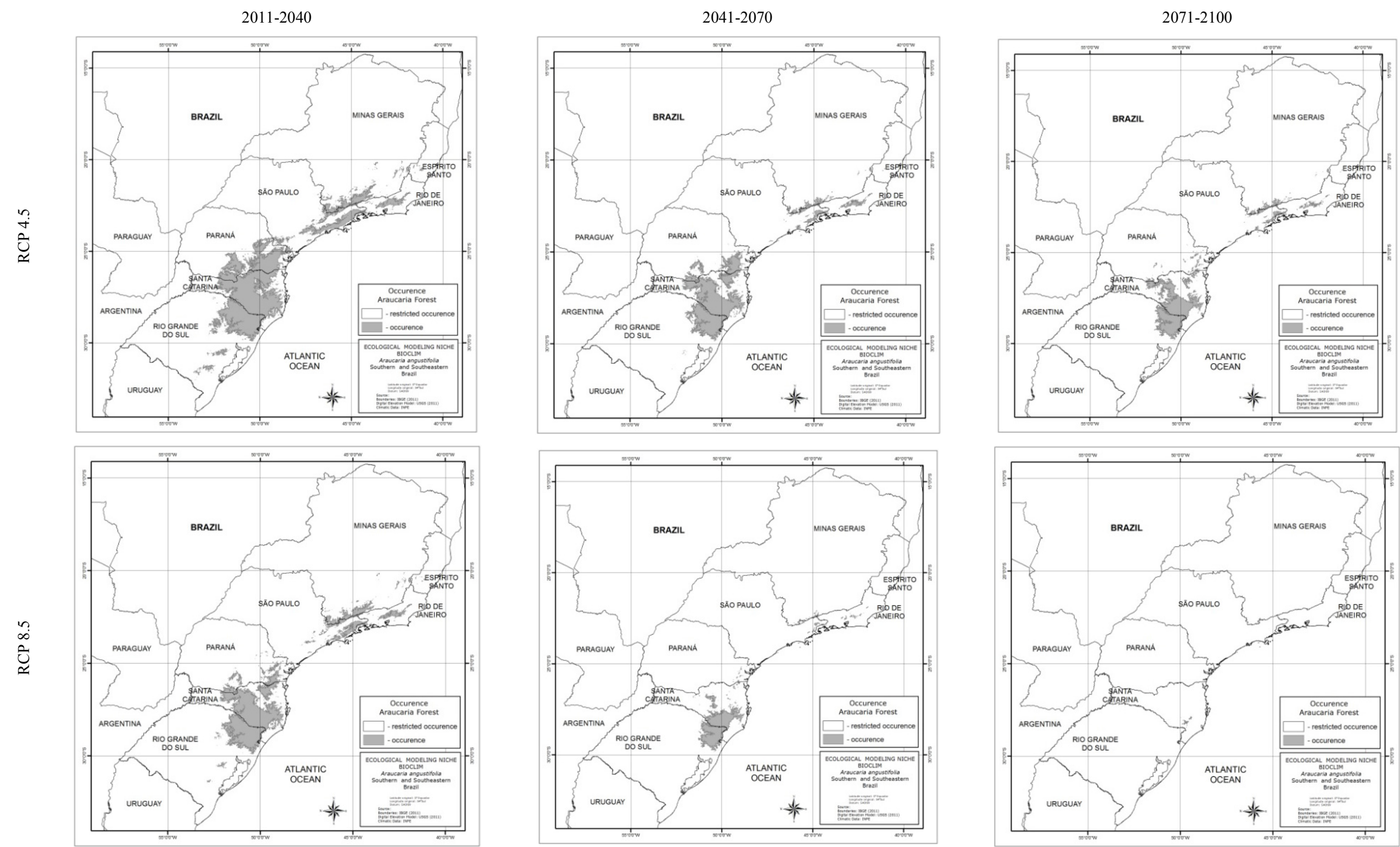

Figure 4. Changes in the fundamental niche occurrence of A. angustifolia based on Bioclim model according to climate change. 


\section{REFERENCES}

[1] Auler, N. M. F.; Reis, M. S.; Guerra, M.P.; Nodari, R.O. (2002). The genetics and conservation of Araucaria angustifolia: genetic structure and diversity of natural populations by means of non-adaptive variation in the state of Santa Catarina, Brazil. Genetics and Molecular Biology 25 (3):239-338.

[2] Behling, H. (2005). Late quaternary vegetation dynamics in southern and southeastern Brazil with a special focus on the Araucaria forests. In: Resumos do $56^{\circ}$ Congresso Nacional de Botânica.

[3] Bittencourt, J. V. M.; Sebbenn, A. M. (2007). Patterns of pollen and seed dispersal in a small, fragmented population of the wind-pollinated tree Araucaria angustifolia in southern Brazil. Heredity 99:580-591.

[4] Carvalho, P. E .R. (1994). Espécies florestais brasileiras:recomendações silviculturais, potencialidades e uso da madeira. Colombo: EMBRAPA-CNPF; Brasília, DF: EMBRAPA-SPI, 639 pp.

[5] Chou, S.C.; Lyra, A.; Mourão, C.; Dereczynski, C.; Pilotto, I.; Gomes, J.; Bustamante, J.; Tavares, P.; Silva, A.; Rodrigues, D.; Campos, D.; Chagas, D.; Sueiro, D.; Siqueira, G.; Marengo, J. (2014). Assessment of Climate Change over South America under RCP 4.5 and 8.5. Downscaling Scenarios. American Journal of Climate Change 3:512-525. http://dx.doi.org/10.4236/ajcc.2014.35043.

[6] Chou, S.C.; Lyra, A.; Mourão, C.; Dereczynski, C.; Pilotto, I.; Gomes, J.; Bustamante, J.; Tavares, P.; Silva, A.; Rodrigues, D.; Campos, D.; Chagas, D.; Sueiro, D.; Siqueira, G.; Nobre, P.; Marengo, J. (2014). Evaluation of the Eta Simulation Nested in Three Global Climate Change Models. American Journal of Climate Change 3:438-454. http://dx.doi.org/10.4236/ajcc.2014.35039

[7] de Sousa, V. A. (Ed.). (2011). Cultivo da araucária. 2. ed. Colombo: Embrapa Florestas, 2010. Versão eletrônica. (Embrapa Florestas: Sistemas de produção, 7). http://sistemasdeproducao.cnptia.embrapa.br/FontesHTML/ Araucaria/CultivodaAraucaria_2ed/.

[8] de Sousa, V. A. (2001). Population genetic studies in Araucaria angustifolia (Bert.) O. Kuntze. Thesis (PhD) Faculty of Forest Sciences and Forest Ecology, Institute of Forest Genetics and Forest Tree Breeding, Georg-August University of Göttingen, $161 \mathrm{pp}$.

[9] de Sousa, V. A.; Lavoranti, O. J.; Chaves Neto, A.; Shimizu, J. Y. (2009). Genetic differentiation among araucaria populations in Brazil. XIII Congresso Florestal Mundial. Buenos Aires, CD-rom.

[10] de Sousa, V.A. (2000). Population genetic studies in Araucaria angustifolia in southern Brazil. Heredity 99:580-591.

[11] de Sousa,V. A.; Sebbenn, A.M.; Hattemer, H.; Ziehe, M . (2005). Correlated mating in populations of a dioecious Brazilian conifer, Araucaria angustifolia (Bert.) O. Kuntze. Forest Genetic 12:107-119.
[12] Dean, W. (1995). A ferro e fogo:a história e a devastação da Mata Atlântica brasileira. São Paulo: Companhia de letras.

[13] Fähser, L. (1981). Die Bewirtschaftung der letzten Brasil-Kiefer-Naturwälder, eine entwicklungspolitische Aufgabe. Forstarchive 52:22-26.

[14] Hueck, K. (1972). As florestas da América do Sul. Brasília:Ed. da Universidade de Brasília, São Paulo:Polígono, 466 pp.

[15] Huntley, B.; Green, R. E.; Collingham, C.; Hill, J. K.; Willis, S. G.; Bartlein, P. J.; Cramer, W.; Hagemeijer, W. J. M.; Thomas, C. J. (2004). The performance of models relating species geographical distribution to climate is independent of trophic level. Ecology Letters 7:417-426.

[16] IBAMA (Instituto Nacional do Meio Ambiente e dos Recursos Naturais Renováveis), 2008. Lista Oficial das Espécies da Flora Brasileira Ameaçadas de Extinção. http://www.ibama.gov.br/.

[17] Jiménez-Valverde, A.; Lobo, J.M.; Hortal, J. (2008). Not as good as they seem: the importance of concepts in species distribution modelling. Diversity and Distributions 14:885-890.

[18] Klein, R. (1960). O aspecto dinâmico do pinheiro brasileiro. Sellowia 12:17-48.

[19] Klein, R.M. (1984). Aspectos dinâmicos da vegetação do sul do Brasil. Sellowia 36:5-54.

[20] Ledru, M. P.; Braga, P.I.S.; Soubies, F.; Fournier, M.; Martin, L. Suguio, K.; Tuerc, Q. (1996). The last 50,000 years in the Neotropics (southern Brazil): evolution of vegetation and climate. Paleogeography, Paleoclimatology, Paleoecology 123:239-257.

[21] Luoto, M.J.; Heikkinen, R.K.; Saarinen, K. (2005). Uncertainty of bioclimate envelope models based on the geographical distribution of species. Global Ecology and Biogeography 14:575-584.

[22] Mantovani, A.; Morellato, P. C.; Reis, M. S. (2006). Internal genetic structure and outcrossing rate in a natural population of Araucaria angustifolia (Bert.) O. Kuntze. Journal of Heredity 97(5):466-472.

[23] Medeiros, J. D. (2000). Da exploração e conservação da Araucaria angustifolia. Parecer do Ministério Público Federal.

[24] Muñoz, M.E.S., Giovanni, R., Siqueira, M.F., Sutton, T., Brewer, P., Pereira, R.S., Canhos, D.A.L.; Canhos, V.P. (2009). 'OpenModeller:a generic approach to species' potential distribution modelling'. GeoInformatica. http://dx.doi.org/10.1007/s10707-009-0090-7.

[25] Peterson, A.T. (2001). Predicting species geographic distributions models based on ecological niche modeling. Condor 103:599-605.

[26] Puchalski, A.; Mantovani, M.; Reis, M.S. dos. (2006). Variações em populações naturais de Araucaria angustifolia (Bert.) O. Kuntze associada a condições edafoclimáticas. Scientia Florestalis 70:137-148.

[27] Raxworthy, C. J.; Martinez-Meyer, E.; Horning, N. Nussbaum, R.A.; Schneider, G.E.; Ortega-Huerta, M.; Peterson, A.T. (2003). Predicting distribution of known and unknown reptile species in Madagascar. Nature 426:837-841. 
[28] Reitz, R.; Klein, R.M. (1966). Araucariáceas. Herbário Barbosa Rodrigues.,62 pp.

[29] Shimizu, J.Y., Jaeger, P., Sopchaki, S.A., (2000). Variabilidade genética em uma população remanescente de Araucária no Parque Nacional do Iguaçu, Brasil. Boletim de Pesquisa Florestal 41:18-36.

[30] Stefenon, V. M. (2007). The distribution of the genetic diversity in Arucaria angustifolia and its implications for the genetic conservation of the species'genetic resources. Thesis $(\mathrm{PhD})$ - Faculty of Forest Sciences and Forest Ecology, Institute of Forest Genetics and Forest Tree Breeding, Georg-August University of Göttingen, 120 pp.

[31] Stefenon, V.M.; Gailing, O.; Finkeldey, R. (2008). Genetic structure of plantations and the conservation of genetic resources of Brazilian Pine (Araucaria angustifolia). Forest Ecology and Management 55:2718-2725.

[32] Valgas, R. A. (2008). Análise multivariada aplicada no mapeamento da divergência genética de subpopulações de
Araucaria angustifolia por marcadores moleculares. Dissertação de mestrado apresentada ao curso de pós-graduação em métodos numéricos na UFPR, 139 pp.

[33] Valgas, R. A., Chaves Neto, A., Lavoranti, O. J.; Sousa, V. A. (2009). Cluster analysis applied in mapping the genetic divergence of populations of Araucaria angustifolia (Bert.) O. Kuntze by isoenzymatic markers. In: Proceedings of the 10th WSEAS International Conference on Mathematics and Computers in Biology and Chemistry, Prague, Czech Republic, 87-91.

[34] Wrege, M. S.; Higa, R. C. V.; Britez, R. M. ; Garrastazu, M. C.; Sousa,V. A; Caramori, P. H.; Radin, B.; Braga, H. J. (2009). Climate change and conservation of Araucaria angustifolia in Brazil. Unasylva 231/232 (60):30-33.

[35] Wrege, M.S.; Steinmetz, S.; Reisser Jr, C.; Almeida, I.R. (2011). Atlas Climático da Região Sul do Brasil: Estados do Paraná, Santa Catarina e Rio Grande do Sul. Pelotas: Embrapa Clima Temperado; Colombo: Embrapa Florestas, $336 \mathrm{pp}$. 